\title{
A call for a blue degrowth: Unravelling the European Union's fisheries and maritime policies
}

Maria Hadjimichael

Independent Researcher, Nicosia, Cyprus

E-mail address: Maria.m.hadjimichael@gmail.com.

This is the accepted manuscript of a paper originally published in Marine Policy. You may find the final, formatted version at 10.1016/j.marpol.2018.05.007.

\section{ABSTRACT}

Terms like blue growth (as well as the blue economy) have become the new buzzword inscribing a new era where the seas are recognized as potential drivers for the European economy. It is nevertheless, through this same logic of limitless economic growth, marine resources have been unsustainably exploited despite numerous institutional attempts to tackle overfishing. The aim of this paper is to point at the contradictions inherent in the objectives of the blue economy, and question the belief that ecological, social and economic targets can be achieved under (blue) growth-centred policies. An analysis of the (failing) policies for a 'sustainable use of marine resources' will be conducted and exemplified through an analysis of the main tools the EU has promoted as solutions to the fisheries crisis (sustainable consumption, privatisation of fish, fishing in waters of third countries and marine aquaculture). Additionally, the sectors promoted by the EU's Blue Growth strategy (marine aquaculture, coastal tourism, marine biotechnology, ocean energy and seabed mining) will also be evaluated in order to question this new vision for the seas and the coast. Through the introduction of the concept blue degrowth, this article aims to open up a more critical discussion around the blue growth strategy by highlighting the inherent dangers which lie in such economic strategies.

\section{Introduction}

Since the publication of the European Union's Blue Growth Agenda in 2012, the term Blue Growth has been used to describe a new era, where the blue economy is an important feature of the European economy. It has been used in the aquatic development discourse in many nation states, regionally as well as internationally since the Rio+20 conference [21]. The Food and Agriculture Organisation of the United Nations [33] defines Blue Growth as a cohesive 
approach for environmentally compatible, integrated and socioeconomically sensitive management of aquatic resources including marine, freshwater, and brackish water environments [67] and the World Bank [81] as "the sustainable use of ocean resources for economic growth, improved livelihoods and jobs, and ocean ecosystem health". For the EU, "Blue Growth is the long term strategy to support sustainable growth in the marine and maritime sectors as a whole". ${ }^{1}$ To make this strategy more operational and efficient, a new tool known as Maritime Spatial Planning (MSP), which is about planning when and where human activities take place at sea has been created. Its main purpose, according to the EU Directive, "is to promote sustainable development and to identify the utilisation of maritime space for different sea uses as well as to manage spatial uses and conflicts in marine space" ([32]; point 19). Through a Joint Communication titled "Limits to Blue Growth' [23], environmental NGOs have already expressed their concerns with regards to some of the priorities set in the EU's Blue Growth Communication, and called "upon Ministers and policy makers to fully enshrine Good Environmental Status by 2020 and the precautionary principle as prerequisites for the Integrated Maritime Policy and a blue growth agenda". ENGOs are right to raise these concerns. Previous experiences suggest that it is unrealistic to claim that there can be a sustainable natural resource exploitation within a framework of unlimited economic growth. Through an investigation of EU fishery policies, this article aspires to question the belief that ecological, social and economic targets can be achieved under a (blue) growth imaginary.

In a recent special section in Marine Policy titled 'What is blue growth? The semantics of "Sustainable Development" of marine environments', Eikeset et al. [21] attempt to establish a better under-standing of the various definitions of blue growth. They point to the fact that for some, blue growth is about maximizing economic growth, whilst for others the focus is on sustainability. This multiplicity of understandings, is one of its biggest constraints. Burgess et al. [14] describe blue growth as "the newest of many recent calls for more holistic management of complex marine socio-ecological systems", and "an ambitious framework for ocean management" however is somewhat a shift away from reality. As indicated by its name, as well as how it is presented by the European Commission, Blue Growth is an economic strategy, which identifies the seas and oceans as drivers for the economy and promoted through the use of numbers (whether these are number of jobs or gross added value). ${ }^{2}$ Though funding and promotion for the five priority areas promoted under the Blue Growth strategy (ocean renewable energy, aquaculture, maritime and coastal tourism, exploitation and mining of marine mineral resources and blue biotechnology) are already under way, discussion as to how environmental sustainability can be ensured is ongoing. Some researchers point out the need to study the capacity of marine ecosystems to "supply the required services" for blue growth given the indicators of Good Environmental Status and explore the required trade-offs between economic, social and environmental aspects [61], whilst others suggest rules of thumb to build a solution-oriented, realistic and practical approach for pragmatic blue growth [14].

Not much research has been done to explore the links between blue growth, sustainability and specific sectors, and what has been done has focused on fisheries. This is understandable given

\footnotetext{
${ }^{1}$ European Commission $>$ Maritime affairs $>$ Integrated maritime policy $>$ Blue growth: https://ec.europa.eu/maritimeaffairs/policy/blue_growth_en.

${ }^{2}$ The EU for example suggests that the 'blue' economy represents roughly 5.4 million jobs and generates a gross added value of almost $€ 500$ billion a year.
} 
the long history of fishing and the resulting societal interaction with the sea and consequently its impact. Despite the long history, there are conflicting views on the blue growth potential in fisheries. Pauly [72] suggested that it is small scale fisheries which have the features that make them compatible with a sustainable blue economy, whereas Hilborn and Costello [50] point to possibilities using current harvesting technology either after the rebuilding of stocks either in cases where in some (developed) countries harvesting practises are conservative across some species.

Precisely due to this history, the dangers and the potential of the Blue Growth strategy can be explored through the fisheries sector. Since the period after WWII, when fisheries started behaving like any other sectors of the economy, the industrialization of the fishing industry and the commodification of seafood, has led to the intensification and eventually the unsustainable exploitation of marine resources $[54,71]$. The increase in seafood production is directly relevant with the advance of the free market which incentivized and gave rise to capital intensive and efficient practices through a push for technological advances and industrial mode fisheries [54]. It is now agreed among scientists that global exploitation limits have been reached and recovery of depleted stocks must become a cornerstone of fisheries management [82]. According to the latest FAO's report 'The State of World's Fisheries and Aquaculture - 2016', the share of assessed commercial fish stocks within biologically sustainable levels decreased from $90 \%$ in 1974 to $68.6 \%$ in 2013 , thus, $31.4 \%$ of fish stocks were estimated as fished at a biologically unsustainable level and therefore overfished.

In the EU particularly, $60 \%$ of fish stocks for which there are available data were assessed to be outside safe biological limits and $93 \%$ of assessed fish stocks in the Mediterranean Sea were overfished in 2015 [74]. The EU is a major consumption market of seafood products in the world with almost 13 million tonnes representing EUR 54 billion during 2013-2014 [31], and much of this supply is imported (the EU was the first net importer of seafood products in 2015) [29]. In its 2016 annual report on self-sufficiency in fish consumption in the EU, the New Economic Foundation (NEF) calculated that in 2016, the EU fish dependence day was the 13th of July, indicating that almost half of fish consumed in the EU is sourced from non-EU waters (this calculation included fish production from marine aquaculture [68].

Decision-making bodies at different levels (national, regional and international) have come up with different solutions, with either legally binding and non-binding tools as a solution to the global fisheries crisis. Such solutions include input controls (restrictions placed on the intensity of fishing/fishing effort), output controls (direct limits on the amount of fish coming out of a fishery) and market-based controls (such as ecolabels). One of the focus of the paper is an analysis of the fisheries policies and particularly the impact of efforts to ensure a limitless supply of fish resources in the EU. The fisheries sector is one of the most regulated sector in the $\mathrm{EU}$, and despite the increase in the number of regulations over time this has not led to the anticipated reduction in landings nor has it helped tackle overfishing [45]. Much has been written on the reasons behind the failure of the EU's fisheries policy to protect fish stocks and the coastal communities depended upon them, such as for example the unwillingness of decision-makers to incorporate social objectives [76], as well as the contradictory and incompatibility of the objectives of the EU fisheries policy, namely conservation, sus- tainability and economic exploitation [58,79].

The aim of this paper is to introduce the concept of sustainable blue degrowth as an alternative to the growth-driven policies of the EU in general and of its maritime and fisheries 
policies in particular. As a starting point, it is important to highlight that sustainable (blue) degrowth is not meant to offer a single operational criterion, but a multi- faceted framework linked with a political vision that can be socially transformative [55]. Through an analysis of the EU's fisheries and maritime policies, this article will bring forward the ecological and social concerns over the implementation of the blue growth strategy. Eight elements will be analysed; three policies within the CFP (eco- labelling, Individual Transferable Quotas, and Fisheries Partnership Agreements); and all five policies within the Blue Growth Strategy. Following the introduction, a short description of the newly introduced blue degrowth concept will be presented. Section 3 will provide a policy

analysis and an assessment of the EU's attempts to address the fisheries crisis whilst seeking to find ways to 'sustainably' satisfying people's appetite for fish. Section 4 will henceforth attempt to evaluate the EU's new vision for the seas and the coast, namely the Blue Growth strategy. Finally, through reflecting on these two, a discussion will follow before concluding.

\section{The concept of blue degrowth}

This paper steps away from the mainstream discussions about the 'sustainable use of the sea and its resources' and the 'win-win' scenarios of sustainably exploiting the sea, and brings forward a new standpoint; the notion of degrowth. Degrowth is defined as an equitable downscaling of production and consumption that increases human well-being and enhances ecological conditions at the local and global level, in the short and long term [73], whilst the term sustainable degrowth is understood as an equitable and democratic transition to a smaller economy with less production and consumption [63]. The underlying debate around the notion of degrowth revolves around the belief that economic growth is both possible and desirable and a critique on (what Georgescu-Roegen described as) the "growth mania" of mainstream economics (for a thorough analysis of this debate see [57]). Daly's (1991) steadystate economy [49], Meadows et al. [65] 'Limits to Growth' as well as the more recent Jackson's [52] 'Prosperity without Growth' have been important in the formation of the notion.

There are other alternative concepts which have been put forward as umbrella concepts. of the concept of 'sustainable development' as put forward in the Brundtland report for example is a prominent example. Another concept is that of a-growth, a concept which suggests that we should continue striving for effective implementation of environmental and complementary policies and be indifferent about growth [77]. Degrowth supporters nevertheless argue that agrowth is unlikely to be implemented effectively within the current socio-political context [55], and that there is a need to de-link sustainability and growth since environmental sustainability is not compatible with economic growth $[2,51,63]$.

Degrowth is not merely an economic analysis. It has its foundations on more philosophical, cultural, anthropological and institutional critiques of the notions of growth and development such as those made by people like Cornelius Castoriadis and Ivan Illich [55]. Though there has been a reluctance from part of the degrowth community to position itself against capitalism, a critical engagement with the political economy of capitalism and the possibilities of its transformation is a crucial intellectual and political task [4]. As Bookchin [9] argues in 'Remaking Society - Pathways to a green future', "to speak of 'limits to growth' under a capitalistic market economy is as meaningless as to speak of limits of warfare under a warrior society". 
Sustainable degrowth has not been discussed in the context of marine and fisheries discussions. There has been some research which modelled the possibilities of marine fisheries and aquaculture to satisfy the consumption demands of a growing population $[66,80]$ without consumption critical analysis of this growing demand. Jacquet [54] examined the causes of the marine fisheries crisis, and suggested that "ultimately, the human appetite is at the root of the marine fisheries crisis. But religion, technology, population pressure, science and our economic systems have provided vehicles for human appetite and thus contributed to overfishing".

Barbesgaard [5] suggests that the increasingly hegemonic nature of policy proposals linked with the blue economy with the pretext of "saving the remaining aquatic species (reform of national fisheries policy and top-down conservation measures), mitigating climate change (so-called blue-carbon initiatives) and feeding the world (through aquaculture and/or 'sustainable' large-scale fisheries)" (p. 2) undermine and preclude progressive and transformative solutions as well as the small-scale fishers' rights who have started framing their struggle in the broader struggle for 'food sovereignty'.

\section{The EU fisheries and aquaculture policies}

"Growth economies do not know how to degrow. They collapse", and this can have socially damaging consequences ([56]; p. 172). Techno- logical and market fixes have made the continuous provision of marine resources possible. As we have seen in a number of cases however, this has led to stock collapses, and what Pauly et al. [70] described as the 'fishing down of the marine food web'. Consequently, the fisheries sector has been omitted from the Blue Growth Strategy's priority areas since, due to the state of the fish stocks, economic growth potential is limited. This is contrary to marine aquaculture where technological advances create the conditions that allow further growth. Fish consumption is nevertheless encouraged by the EU, which argues that through a framework of legal tools as well as voluntary guidelines, (growing) consumption levels can be provided for. This section deliberates over the four main policies which form an integral part of the EU's plan to provide Europe with fish. The promotion of responsible consumption on one hand and a 'rights-based management' in the form of 'Individual Transferable Quotas' (ITQs) are market based tools. Fisheries Partnership Agreements (FPAs) (between EU vessels and third countries), and marine aquaculture have become the means through which the gap between the demand and the supply of seafood is filled. The following sub-sections, highlight how technological and market fixes can create externalities of the ecological as well as the social issues at hand.

\section{Responsible consumption / Eco-labels}

Following the rise in the role of the market in other sectors, sustainable fish eco-labels have come to play an important part in fisheries management [47]. This is reflected in DG MARE's sustainable fish consumption campaigns which were launched in 2011 with the 'choose your fish' campaign. The campaign stated that "citizens have tremendous influence on the fishing economy. Their buying decisions and choices shape the whole sector, from the fishmonger's orders or the frozen assortment on supermarket shelves to the skipper's decision to target a particular species" [25]. 
The campaign was part of the Common Fisheries Policy ${ }^{3}$ (CFP) reform package and urged consumers to 'know their fish' (where it comes from, the state of the stock, and if it's the right size), discover new flavours and discover other lesser-known species, and, buy sustainable seafood where possible. In January 2014, the new 'Inseparable'4 campaign was launched which highlighted that "as consumers and market actors we have to be aware that what, when and how we eat, buy and sell seafood has a huge impact on this precious food source". The campaigns urged consumers to eat more fish as long as they can ensure it's from a sustainable source. "Varying the types of fish they eat" ${ }^{5}$ can fill part of the gap between supply and demand whilst marine aquaculture would fill the rest. The idea is that society's demand for fish can be partly filled through the consumption of previously non consumed species.

Is it possible however to continue trying to (sustainably) cover for an increasing appetite for fish of an increasing human population ${ }^{6}$ ? What are the ecological and the social externalities of such attempts? There are a number of critiques and debates on the effectiveness of ecolabelling in providing solutions to the overfishing issue [36,37,53]. Research on the most known and reliable fisheries certification suggests that the increasing demand for products carrying the label have led to the scheme to make questionable claims in order to increase and retain market shares [47]. Additionally, a review of formal objections to the most known and accepted fishery certification, the Marine Stewardship Council, indicates that the MSC's principles for sustainable fishing (sustainability of the target fish stock, low impacts on the ecosystem, and effective, responsive management) are too lenient and discretionary, and therefore misleading [15]. Finally, it is argued that certification schemes often subordinate the 'beneficiaries' of the certification, be that the environment, the producers, or both, to the demands of consumers and the market more broadly [39]. The exclusive nature of a label has the potential to exclude the smaller producers $[40,59]$ who have the features that make them compatible with a sustainable blue economy [72].

\section{Individual transferable quotas}

ITQs ${ }^{7}$ have become another market tool (like the certification schemes) which through allowing fish opportunities to be bought and sold between individuals and companies. ITQs are 'transferable' meaning that as any market instrument, there are incentives for efficient harvesters (who tend to be the larger scale operators) to acquire quota from less efficient harvesters (who tend to be the smaller scale operators) something which will in turn lead to a

\footnotetext{
${ }^{3}$ The EU's umbrella framework for the management of fisheries resources.

${ }^{4}$ http://ec.europa.eu/fisheries/inseparable/en/home.

${ }^{5}$ http://ec.europa.eu/fisheries/documentation/publications/how_do_you_choose_en. pdf.

${ }^{6}$ The issue of an increasing human population does not take into account issues of distributive justice however and assumes an equal distribution of fish produced to the increasing population something which is not the case.

${ }^{7}$ ITQs are the evolution of the Total Allowable Catches (TACs) meaning catch limits set for the most commercial fish stocks and which are shared between EU countries in the form of national quotas with each State deciding how these quotas are divided among their fishers.
} 
reduction in harvesting capacity [43,62]. Owning ITQs implies ownership over future fisheries opportunities and transferability implies that the rights can be capitalised -and hence used as collateral.

During the 2012 reform of the CFP, ITQs became part of the official agenda of the EU fisheries policy under the name of Transferable Fishing Concessions (TFCs). TFCs have become part of the official package promoted by the EU for the rationalisation of the EU fisheries sector [26]. Though the non-paper ${ }^{8}$ on the TFCs' produced by the $\mathrm{EC}^{9}$ suggests to draw upon the positive experience of a number of Member States who introduced ITQs, it fails to also draw upon the negative experiences. A study for example in the eighteen countries which introduced ITQs to manage several hundred stocks identified that the implementation of ITQs did not translate into consistent changes in stock biomass [16]. Denmark more specifically, introduced ITQs for the pelagic fleet in 2003 and in 2007 for the demersal ${ }^{10}$ fleet, something which led to a $50 \%$ and $30 \%$ decrease of the fishing capacity respectively. Nevertheless, analyses also showed that the resource rent (sur- plus value) in an ITQ-based fishery might not differ very much from the resource rent in a well-managed fishery based on effort restrictions ${ }^{11}$ [3]. Additionally, implications for smaller operators can be detrimental as it has been observed in the United Kingdom and Denmark [12,3]. In Iceland, approximately $60 \%$ of the (land-based) jobs in fish processing have vanished since the beginning of the 1990s, and by 2007, 10 of the largest quota holders controlled $51.7 \%$ of the ITQ market [7].

\section{Fisheries Partnership Agreements}

Over a quarter of the fish caught by European fishing boats are taken outside EU waters. This can be done through either bilateral or multilateral agreements. ${ }^{12}$ FPAs, also known as Sustainable FPAs since 2015, are bilateral agreements between the EU and a non-EU country, and "intend to allow EU vessels to fish for surplus stocks in that country's exclusive economic zone (EEZ), in a legally regulated environment". There are currently 13 FPAs, 10 tuna and 3 mixed stock agreements (along the shores of Africa and the Indian Ocean), out of which only that with Greenland is with a non-African-Caribbean-Pacific (ACP) country. ${ }^{13}$

\footnotetext{
${ }^{8}$ Non-papers are discussion papers which are not part of formal business but facilitate discussions and negotiations.

${ }^{9}$ http://ec.europa.eu/fisheries/reform/docs/tfc_en.pdf.

${ }^{10}$ Demersal fleet is the fleet which fishes the zone at or near the bottom of the sea, often relates to trawling practices.

${ }^{11}$ The restrictions on the amount of effort that may be expended in harvesting a fish stock by for example limiting the number of boats, horsepower exerted etc.

${ }^{12}$ Around $8 \%$ of EU catches (2004-06) are made under fishing agreements with countries outside the $\mathrm{EU}$, while another $20 \%$ are taken on the high seas, mainly in regions under the care of regional fisheries management organisations (RFMOs) (http://ec. europa.eu/fisheries/cfp/international/index_en.htm).

${ }^{13}$ These countries include Cape Verde, Ivory Coast, Sao Tomé and Principe, Gabon, Madagascar, Senegal, Comoros, Seychelles, Mauritius and Kiribati for tuna, and Morocco, Greenland and Guinea-Bissau, for mixed fisheries.
} 
Before the 2002 reform of the CFP, such agreements were characterized as "pay, fish and leave" [18]. Back then, though they generated annually, a value added of average $€ 694$ million in the EU Member States through processing and marketing of fish, which is three times more than the benefits accruing to ACP countries through the signing of fisheries agreements with the EU [41]. Efforts have been made since by the EU to improve these agreements. Efforts included requirements for increasing the degree of technical support and transfer of knowhow granted to the host country, as well as the amount of financial contributions to the host country (aiming to strengthen the administrative and scientific capacity through a focus on sustainable fisheries management, monitoring, control and surveillance). The need for a 'human rights clause' has also come up over the last years, with the European Parliament blocking the renewal of the EU-Morocco agreement in December 2011 as it allowed EU vessels to fish in the waters of the non- self-governing territory of Western Sahara, ${ }^{14}$ in a way which was violating the right to self-determination of the Sahrawi people [75]. The agreement has been re-established since and there is currently a case at the European Court of Human Rights on the legality of such EU agreements with Morocco [13].

Though there have been a number of attempts to improve these agreements but concerns over social and ecological consequences still remain. Some of the main issues which accompany these agreements include the lack of scientific information to calculate the biological surplus, the mismatch between local regulations and the European regulations on technical measures (for example minimum mesh size), the lack of transparency on the calculation of the surplus, the actual landings and their value, and the uncertainty of how the money paid by the EU are actually spent [38]. Often, funds do not reach the intended purposes, fish stocks are decreasing and the lives of fishworkers in contracting states are harder than ever. Additionally, a number of EU fisheries subsidies such as grants for vessel construction, tax breaks (e.g. on fuel), infrastructure development, subsidised loans, market support, etc. leads to unfair competition with the local fleet, especially in the artisanal sector [41]. Finally, there are also concerns over the fees paid by the EU since for example in the case of Madagascar [60], research has identified that since 1986, even though EU quotas increased by $30 \%$, the fees paid by the EU decreased by $20 \%$ whilst Madagascar's treasury income from these agreements decreased by $90 \%$. These agreements therefore are putting in danger the well-being of coastal communities in ACP countries and their marine environment tin order to satisfy the drive of European companies.

\section{Marine aquaculture}

"Aquaculture is one of the world's fastest growing food sectors, fish farming, accounts for about half of the fish eaten worldwide every year with that figure on the rise.

Simply put, without aquaculture there would not be enough fish to feed the world population. This would mean having to take more fish from our seas and jeopardising

\footnotetext{
${ }^{14}$ The agreement was approved in October 2013, though whether it complies with International law is still disputed: http://www.europarl.europa.eu/news/en/newsroom/ content/20131206IPR30021/html/MEPs-approve-renewed-EU-Morocco-Fisheriesagreement.
} 
the long term sustain- ability of our wild fish stocks". ${ }^{15}$

The economic importance of the marine aquaculture sector has led to its promotion in Europe by institutions at both EU and national level and facilitation through deregulation of the sector and financial assistance (through subsidies) [44]. Its inclusion in the Blue Growth strategy suggest the intensification of these policies, without however attempts being made to understand what the potential impacts are on coastal communities. Thus, though on one hand there is environmental damage to coastal ecosystems from marine aquaculture (through wastes off- loads, introduction of alien species, genetic interactions, disease transfer, release of chemicals, use of wild recourses, alterations of coastal habitats and disturbance of wildlife) which in turn lead to socio- economic and environmental problems [35,44], there are also social impacts.

Marine aquaculture experience in different parts of the world (only to mention India, Chile, Greece and Turkey) indicate that there are important socio-environmental conflicts arising from the push for the growth of fish farms [1,6,69,83]. Ertör and Ortega-Cerdà [22] analysed 24 finfish aquaculture conflicts around Europe and suggested that these conflicts are linked to environmental justice concerns though this remained under addressed in the peer-reviewed literature. Environmental justice arguments used included a call for a just distribution of burdens, benefits and risks generated by marine finfish aquaculture activities; for recognition of relevant stakeholders; for adequate access to information and tools to effectively participate and influence decision-making processes; and for an enhancement of the capabilities and social functioning of individuals and communities. A political ecology perspective on the expansion of marine aquaculture can suggest that within the current institutional and decisionmaking structures, there is the danger of continuously undermining the rights of coastal communities and other users of the sea [46].

\section{The EU's new maritime strategy for blue growth}

As indicated in the previous section, the contradiction that is inherent in the EU's fisheries objectives [79] and the disavowal of the existence of limits to blue growth, has led to overfishing on one hand, and endangers the well-being of fisher communities on the other. Rather than accepting that there are limits to (blue growth), the European Commission [24] explores through its Blue Growth strategy the growth potential in other sectors. In its Communication 'Blue Growth - opportunities for marine and maritime sustainable growth' describes the sea and the coasts as "drivers of the economy", and the Blue Growth strategy itself as "an initiative to harness the untapped potential of Europe's oceans, seas and coasts for jobs and growth". In the final report prepared by a consultancy contracted by the EC to explore the potential of the oceans, the seas and the coasts Blue Growth is considered to be the "grounded belief that seas, coasts and oceans can play a pivotal role in the solutions" to the tensions "between the current methods of production, of consumption and the future availability of non-renewable resources." [19].

Through an analysis of the job-creation potential, as well as the potential for research and

${ }^{15}$ http://ec.europa.eu/fisheries/inseparable/en/farmed-eu. 
development to deliver technology improvements and innovation it has been evaluated that further growth is possible in a number of areas which are highlighted within the strategy; marine aquaculture, coastal tourism, marine biotechnology, ocean energy and seabed mining. Through Blue Growth, these five sectors will be supported by "fostering investment in research and innovation, promoting skills through education and training and by removing the administrative barriers that hamper growth". ${ }^{16}$ The aim of this section is to briefly highlight some of the caveats and challenges which might arise from the promotion of these specific sectors. Though it is too early to study the social, environmental and economic impacts of the Blue Growth strategy, an initial appraisal is attempted using the environmental impact assessments conducted as well as existing literature. It is important to note that, unlike the analysis presented in Section 3, which is for policies with a rather long history, Section 4 attempts to problematize over sectors which are relatively new. This is particularly the case for the marine biotechnology and ocean renewable energy sectors.

The contribution of marine biotechnology is suggested to be the development of new pharmaceuticals or industrial enzymes that can withstand extreme conditions and the sector is presented as a niche sector with the potential to produce mass-market products in the long run. No significant environmental impacts of this activity were identified as well as only a few tensions between the sector and other marine activities [20] and this is something that is supported by a study into the literature. However, one of the points in the EC's Communication (2012a) is that intensified efforts to manufacture biofuels and other chemicals from algae arose from concerns about growing crops for biofuels on land. Thus, it is yet to be seen whether the land grabbing which has been taking place in countries in Africa, South and Central America and Asia for the production of biofuels will be intensified in the form of ocean grabbing $[10,11]$.

Ocean renewable energy has according to the EC's Communication (2012b) the potential to enhance the efficiency of harvesting the European energy resource, minimize land-use requirements of the power sector and reduce the European greenhouse gas emissions. Offshore wind power generation could meet $4 \%$ of electricity by 2020 and $14 \%$ by 2030 with wave and tidal power offering a more regular and predictable source though are not yet commercially competitive. In the corresponding impact assessment, the EC suggested that data on the environmental impacts of ocean energy is limited and more research and development along with a better exchange of information will be required to understand and mitigate the adverse environmental impacts of ocean energy installations [28].

Tourism is a sector which has already received attention with regards to its social and ecological impacts. Additionally, in a call for contributions for a special issue on 'Tourism and Degrowth', Fletcher et al. [34] point out that there is a need for discussions on sustainable tourism to engage with the discourse of degrowth and highlights that though tourism is commonly portrayed as a relatively clean sector, its growth requires vast amounts of materials and energy to be trans- formed into capital and its questioning is imperative to challenging the growth imperative. Thus a different approach to tourism and economics has recently been proposed, following alternative forms of development, and aiming towards a just and materially responsible society [48]. This somewhat conflicts with the promotion of maritime, coastal and cruise tourism through the Blue Growth strategy through the focus on its growth

${ }^{16}$ http://balticseaconference.eu/news/2013/8/21/what-is-blue-growth. 
and jobs potential in its relevant strategy [30]. Literature suggests however that it is the local communities and the environment which will have to face the burden of such growth $[42,8]$. Tourism is an industrial activity which consumes (sometimes over-consumes) re- sources, creates waste and has specific infrastructure needs, whilst it is a private sector whose investment decisions are predominantly based on profit maximisation [64]. Investigation of tourism related interactions often points to conflicts between different interest groups contesting ownership and control of the coast with examples along the European coastline varying from issues such as the privatisation of the Mediterranean coastline due to tourist-related developments, conflicts between fisheries, aquaculture, marine protected areas and tourism as well as socio-cultural and economic impacts [8]. Thus, though if care-fully implemented it can indeed be a win-win situation, promotion of maritime tourism requires careful implementation which respects local socio-ecological dynamics.

The most controversial sector from those promoted within the Blue Growth strategy is sea bed mining. The sector is promoted with the premise that advances in underwater technology means that mining companies can exploit the seafloor and contribute towards the growing global demand for non-energy raw materials. It has been calculated that the global annual turnover of marine mineral mining can be expected to grow from virtually nothing to $€ 5$ billion in the next 10 years and up to $€ 10$ billion by 2030 [27]. The environmental impacts disclosed in the relevant Blue Growth study on marine mineral resources acknowledge that seabed mining has "considerable environmental concerns and un-certainties", the "effects on the ecosystems are difficult or even near impossible to predict" and that "processing demands high energy input and the use of chemicals" [20]. The EC suggests that to overcome this hurdle funding should also flow towards assessing and minimising environmental impacts of seabed mining. Van Dover et al. [78] however suggest that despite potential technological advances, mining-induced impacts cannot be remedied given the very slow natural rates of recovery in affected ecosystems and thus focus must be on avoiding and minimising harm.

Seabed mining by European Companies will not have its only focus in EU waters but rather within the high seas and third countries' waters. Specifically, in the relevant Blue Growth study ([20]; p. 28), a specific project called the Nautilus project in Papua New Guinea (PNG), which won the first lease to mine the ocean floor for gold and copper, is presented as a successful pilot. Further research however has shown a grassroots counter-movement opposing the project. In their blog, the Papua New Guinea Mine Watch, together with the Pacific Network on Globalisation state "PNG is the first country to approve the process of sea bed mining despite vocal opposition by custom land owners, non-government groups, faith-based groups and scientists. Recent research has shown that disregarding indigenous peoples' rights to consent to such projects will only increase the risk to mining industry and investors" ${ }^{\prime 17,18}$.

\section{Discussion}

The primary purpose of this article was to introduce the concept of blue degrowth, as an alternative to the (blue) growth-centred policies which have been promoted across the EU. Through an analysis of eight elements, which form an important part of the EU maritime policy, 3 policy and market-based instruments fostered by the EU (eco-labelling, ITQs and FPAs) and

\footnotetext{
${ }^{17} \mathrm{https} / /$ ramumine.wordpress.com/2014/12/02/png-mining-conference-an- investment-in-destruction/.

${ }^{18} \mathrm{http}: / /$ www.deepseaminingoutofourdepth.org/.
} 
the 5 sectors promoted under the blue growth strategy (marine aquaculture, marine biotechnology, ocean renewable energy, maritime, coastal and cruise tourism and sea bed mining), this article highlighted that a new vision is needed for the seas if we are to ensure not only environmental but also social sustainability. Though the protection of the marine ecosystem and fishers' livelihoods, as well as satisfying fish demand is always part of the dominant fisheries management discourse, a critical reading of this management framework is needed to understand the impact of these policies on issues related to environmental and social justice and democracy. This article puts forward that is not merely the human appetite which is at the root of the fisheries crisis [54]. It is rather neoliberalism as an economic strategy, and the conviction of infinite growth which are at the root of the crisis. The policy analyses presented in this article suggests that whilst the EU has promoted a fisheries governance framework which failed to solve overfishing, it created injustices along the way, conflicts with the values and interests of local communities, and led to further environ- mental deterioration. Thus, there are inherent dangers in attempts to solve overfishing under a vision of continuous economic growth (and therefore through the promotion of increasing consumption). What this paper argues is that what is required is the downscaling of extraction and consumption to match the ecological limits of the sea.

The strong promotion of rights-based management in fisheries have often come to mean the establishment of de facto private ownership over future fishing opportunities, and the establishment of markets where individual transferrable quotas (ITQs) can be traded to optimize efficiency. When efficiency is measured by an optimal outcome which is linked to economic growth, larger operators who tend to have a higher surplus value and thus a higher profit, are valued more since the success of national economies is measured with the country's gross domestic product (GDP). Thus, efficiency indirectly aims for a shift from a higher number and less efficient operators to a few larger ones, leading to a decreasing regional or local access to resources, with impacts on employment, food resource, community wellbeing and culture.

The EU's Blue Growth strategy moves along the same path. By highlighting our increasing (constructed) energy needs (ocean energy), needs for fuels (marine biotechnology), fish (marine aquaculture), minerals (seabed mining) and a certain type of entertainment (tourism), it reinforces the growth paradigm without the appreciation that there are natural limits to growth. This is not to suggest that all put forward in the Blue Growth strategy are problematic. As shown in Section 4, sec- tors such as maritime, coastal and cruise tourism can indeed benefit coastal communities whilst respecting the environment if the sector is planned taking into account the local needs as well as the carrying capacity of the ecosystem. The same can be the case with regards to marine biotechnology. Under the strategy, research and innovation is promoted, such as for example the re-use and the recycling of material, as well as more efficient technologies and the reorganising of existing developed spaces to satisfy society's needs with respect towards local communities and ecosystems. The importance of such innovation is acknowledged. Nevertheless, as the experience of marine aquaculture (and less so that of the more recent seabed mining sector) show(s), if the strategy's motivation is economic growth, the most possible scenario is that the carrying capacity of the ecosystem will be exceeded. It is thus the belief that economic growth must be at the core of public welfare which is highly problematic. The tendency of such policies to explore growth opportunities outwards from the EU can also result in neo-colonial projects operating without the agreement of the local communities. 
Institutions such as the EU are not inherently bad; it is the amalgamation of the values and ideologies which drive them, and the power dynamics and social hierarchies they create, which makes them so. Considering the erosion of democratic rights at the expense of restoring a status quo focusing on economic growth, the role of degrowth strategies can be interpreted as a reaction against traditional centres of public authority (such as the EU, national governments and the market), which have been driving the economic growth ideology, inculcating it as the ultimate goal for achieving social well-being [17]. Re-localization of production, collective ownership and stewardship, are a few ways with which degrowth can facilitate the exploration of new economic systems.

\section{Conclusion}

Blue growth is undoubtedly an economic strategy with its only social component being a count on job creation. This article intended to highlight the inherent issues which lie in such strategies. Through an analysis of the EU fisheries and maritime policies, it is argued that though sustainability as a term is indeed included in the current EU's neoliberal narrative, economic growth is the main and principal driver. This is at the foundation of the ecological and social problems which lie in the oceanic realm. A degrowth approach can serve as a first step towards opening up this discussion. Though there is no question that the concept of blue degrowth might sound vague and problematic to many not accustomed to the degrowth literature, it is imperative for an ecologically viable and socially just use of the oceans. As mentioned in the introduction, though the idea of degrowth has been used to argue for new political visions in a number of different socio-economic sec-tors, it has never been done before for the marine one. Let this be the first of many.

\section{Acknowledgments}

I would like to thank Irmak Ertör for her support and advice in publishing this manuscript. I would also like to thank the editor Marine Policy and the two anonymous reviewers for all their comments and suggestions on previous versions of this manuscript.

\section{References}

[1] M. Adduci, Neoliberal wave rocks Chilika Lake, India: conflict over intensive aquaculture from a class perspective, J. Agrar. Change 9 (2009) 484-511.

[2] J.M. Alier, Socially sustainable economic de-growth, Dev. Change 40 (6) (2009) 1099-1119.

[3] P. Andersen, J.L. Andersen, H. Frost, ITQs in Denmark and resource rent gains, Mar. Resour. Econ. 25 (2010) 11-22.

[4] D. Andreucci, T. McDonnough, Capitalism, in: G. D’Alisa, F. Demaria, G. Kallis (Eds.), Degrowth: A Vocabulary for a New Era, Routledge, UK, 2014, pp. 59-63.

[5] M. Barbesgaard, Blue growth: savior or ocean grabbing? J. Peasant Stud. (2017) 120.

[6] J.R. Barton, A. Floysand, The political ecology of Chilean salmon aquaculture, 19822010: a trajectory from economic development to global sustainability, Glob. Environ. Change 20 (4) (2010) 739-752.

[7] K. Benediktsson, A. Karlsdóttir, European Urban and Regional Studies 18 Crisis and 
Regional Development - Thanks for all the fish, Iceland, 2011, pp. 228-235.

[8] J. Boissevain, T. Selwyn, Contesting the Foreshore. Tourism, Society, and Politics on the Coast (MARE Publication Series No. 2), Amsterdam University Press, Amsterdam, 2004.

[9] M. Bookchin, Remaking Society: Pathways to a Green Future, South End Press, Boston, MA, 1990.

[10] S.M. Borras Jr.et al., Towards a better understanding of global land grabbing: an editorial introduction, J. Peasant Stud. 38 (2) (2011).

[11] S.M. Borras Jr.et al., Land grabbing in Latin America and the Caribbean, J. Peasant Stud. 39 (3-4) (2012).

[12] K. Brookfield, T. Gray, J. Hatchard, The concept of fisheries-dependent communities: a comparative analysis of four UK case studies: shetland, Peterhead, North Shields and Lowestoft, Fish. Res. 72 (1) (2005) 55-69.

[13] C. Bruneau. Sahrawis, EU in standoff over Moroccan trade agreement [online]. Almonitor, 2016. Available from: /http://www.al-monitor.com/pulse/originals/ 2016/07/morocco-eu-farm-trade-deal-western-sahara.html) (accessed 15 October 2016).

[14] M.G. Burgess, M. Clemence, G.R. McDermott, C. Costello, S.D. Gaines, Five rules for pragmatic blue growth, Mar. Policy 87 (2018) 331-339.

[15] C. Christian, D. Ainley, M. Bailey, P. Dayton, J. Hocevar, M. LeVine, J. Nikoloyuk, C. Nouvian, E. Velarde, R. Werner, J. Jacquet, A review of formal objections to Marine Stewardship Council fisheries certifications, Biol. Conserv. 161 (2013) 10-17

[16] C. Chu, Thirty years later: the global growth of ITQs and their influence on stock status in marine fisheries, Fish. Fish. 10 (2) (2009) 1467-2979.

[17] G. D'Alisa, F. Demaria, C. Cattaneo, Civil and uncivil actors for a degrowth society, J. Civil. Soc. 9 (2) (2013) 212-224.

[18] DG MARE, undated. The European Community External Fisheries Policy. Brussels: Commission. Available from: 〈http://ec.europa.eu/fisheries/documentation/ publications/externalpolicy_en.pdf) (accessed 23 August 2015).

[19] ECORYS, Blue Growth: Scenarios and drivers for sustainable growth from the oceans, seas and coasts. Third Interim Report. Final. Call for Tenders No. MARE/ 2010/01, 2012a.

[20] ECORYS, Blue Growth: Scenarios and drivers for sustainable growth from the oceans, seas and coasts. Marine Sub-Function Profile Report. Marine Mineral Resources (3.6). Third Interim Report. Final. Call for Tenders No. MARE/2010/01, 2012b.

[21] A.M. Eikeset, A.B. Mazzarella, B. Davíđsdóttir, D.H. Klinger, S.A. Levin, E. Rovenskaya, N.C. Stenseth, What is blue growth? The semantics of "Sustainable Development" of marine environments, Mar. Policy 87 (2018) 177-179.

[22] I. Ertör, M. Ortega-Cerdà, Political lessons from early warnings: marine finfish aquaculture conflicts in Europe, Mar. Policy 51 (2015) 202-210.

[23] ESEC (European Seas Environmental Cooperation). Limits to Blue Growth. Joint NGO Position, 2012. Available from: 〈http://www.seas-at-risk.org/24- publications/779limits-to-blue-growth-joint-ngo-position-paper.html> (accessed 10 March 2018).

[24] European Commission, Green Paper: Reform of the Common Fisheries Policy, COM (2009) 163, final, 2009.

[25] European Commission. Fisheries and Aquaculture in Europe. No 53, October 2011, 2011a. Available from: 〈http://ec.europa.eu/fisheries/documentation/magazine/ mag53_en.pdf) (accessed 29 August 2016). 
[26] European Commission, 2011b. Proposal for a regulation of the European Parliament and of the Council on the Common Fisheries Policy, COM(2011) 425, final.

[27] European Commission, 2012a. Communication from the Commission to the European Parliament, the Council, the European Economic and Social Committee and the Committee of the Regions. Blue Growth - opportunities for marine and maritime sustainable growth, $\operatorname{COM}(2012)$ 494, final.

[28] European Commission, Commission staff working document. Impact Assessment. Accompanying the document 'Communication from the Commission to the European Parliament, the Council, the European Economic and Social Committee and the Committee of the Regions - Ocean Energy. Action needed to deliver on the potential of ocean energy by 2020 and beyond, SWD(2014) 13, final, 2012b.

[29] European Commission. The EU Fish Market, 2014a. Available from: 〈http://ec. europa.eu/fisheries/market-observatory/documents/10157/bf18cf2c-1b33-440d8870-e05b2644b58b) (accessed 23 August 2016).

[30] European Commission, 2014b. Communication from the Commission to the European Parliament, the Council, the European Economic and Social Committee and the Committee of the Regions. A European Strategy for more Growth and Jobs in Coastal and Maritime Tourism, $\operatorname{COM(2014)~86,~final.~}$

[31] European Commission. The EU Fish Market - 2016 Edition, 2016. Available from: 〈https://www.eumofa.eu/〉 (accessed 23 September 2016).

[32] (The) European Parliament and the Council, 2014. Directive 2014/89/EU of the European Parliament and the Council of 23 July 2014 Establishing a framework for maritime special planning. Journal of the European Union 28.8.2014, L257, 2014.

[33] FAO, The State of World Fisheries and Aquaculture 2016. Contributing to food security and nutrition for all. Rome, 200, 2016.

[34] Fletcher, R., Blázquez-Salom, M., Murray, I., and Blanco-Romero, A. 2017. Journal of Sustainable Tourism - Join the Conversation on Sustainable Tourism: Now Welcoming Submissions for a Special Issue on Tourism and Degrowth. Available from: http://explore.tandfonline.com/cfp/pgas/rsus-si-degrowth-4q2017 [Accessed 10 March 2018].

[35] C. Folke, N. Kaustky, Aquaculture with its environment: prospects for sustainability, Ocean Coast. Manag. 17 (1992) 5-24.

[36] R. Froese, A. Proelss, Evaluation and legal assessment of certified seafood, Mar. Policy 36 (6) (2012) 1284-1289.

[37] R. Froese, A. Proelss, Evaluation and legal assessment of certified seafood, Mar. Policy 36 (6) (2012) 1284-1289.

[38] A. Gagern, J. van der Bergh, A critical review of fishing agreements with tropical developing countries, Mar. Policy 38 (2013) 375-386.

[39] C. Getz, A. Shreck, What organic and Fair Trade labels do not tell us: towards a place-based understanding of certification, Int. J. Consum. Stud. 30 (5) (2006) 490-501.

[40] D. Goodman, Rural Europe redux? Reflections on alternative agro-food networks and paradigm change, Sociol. Rural. 44 (1) (2004) 3-16.

[41] B. Gorez, Policy study: EU-ACP fisheries' agreements, Coalition for Fair Fisheries' Agreements, Brussels, 2005.

[42] S. Gössling, Global environmental consequences of tourism, Glob. Environ. Change 12 (4) (2002) 283-302.

[43] R.Q. Grafton, D. Squires, K.J. Fox, Private property and economic efficiency: a study of 
a common-pool resource, J. Law Econ., XLIII (2000) 679-713.

[44] K. Grigorakis, G. Rigos, Aquaculture effects on environmental and public welfare the case of Mediterranean mariculture, Chemosphere 855 (2011) 899-919.

[45] M. Hadjimichael, G. Edwards-Jones, M.J. Kaiser, Distribution of the burden of fisheries regulations in Europe: the north/south divide, Mar. Policy 34 (4) (2010) 795-802.

[46] M. Hadjimichael, A. Bruggeman, M.A. Lange, Tragedy of the few? A political ecology perspective of the right to the sea: the Cyprus marine aquaculture sector, Mar. Policy 49 (2014) 12-19.

[47] M. Hadjimichael, T.J. Hegland, Really sustainable? Inherent risks of eco-labeling in fisheries, Fish. Res. 174 (2016) 129-135.

[48] C.M. Hall, Degrowing tourism: décroissance, sustainable consumption and steadystate tourism, Anatolia 20 (1) (2009) 46-61.

[49] D.E. Herman, Steady-State Economics, 2nd ed, Island Press, Washington, D.C., 1991.

[50] R. Hilborn, C. Costello, The potential for blue growth in marine fish yield, profit and abundance of fish in the ocean, Mar. Policy 87 (2018) 350-355.

[51] R. Hueting, Why environmental sustainability can most probably not be attained with growing production, J. Clean. Prod. 18 (6) (2010) 525-530.

[52] T. Jackson, Prosperity Without Growth? The Transition to a Sustainable Economy, Sustainable Development Commission, 2009.

[53] J. Jacquet, D. Pauly, Funding priorities: big barriers to small-scale fisheries, Conserv. Biol. 22 (4) (2008) 832-835.

[54] J. Jacquet, Silent water: a brief examination of the marine fisheries crisis, Environ., Dev. Sustain. 11 (2009) 255-263.

[55] G. Kallis, In defense of degrowth, Ecol. Econ. 70 (2011) 873-880.

[56] G. Kallis, C. Kerschner, J. Martinez-Alier, The economics of degrowth, Ecol. Econ. 84 (2012) 172-180.

[57] C. Kerschner, Economic de-growth vs. steady-state economy, J. Clean. Prod. 18 (6) (2010) 544-551.

[58] S. Khalilian, R. Froese, A. Proelss, T. Requate, Designed for failure: a critique of the Common Fisheries Policy of the European Union, Mar. Policy 34 (6) (2010) 11781182.

[59] J. Kurien, Towards a New Agenda for Sustainable Small-Scale Fisheries Development, Trivandrum: South Indian Federation of Fishermen Societies, 1996, p. 48.

${ }_{\text {[60] }}$ F. Le Manach, et al., Who gets what? Developing a more equitable framework for EU fishing agreements, Mar. Policy 38 (2013) 257-266.

[61] A.I. Lilleb $\varnothing$, C. Pita, J.G. Rodrigues, S. Ramos, S. Villasante, How can marine ecosystem services support the Blue Growth agenda? Mar. Policy 81 (2017) 132-142.

${ }_{\text {[62] }}$ S. Macinko, W. Bromley, Property and fisheries for the twenty-first century: seeking coherence from legal and economic doctrine, Vt. Law Rev. 28 (2004) 623-661.

[63] J. Martínez-Alier, U. Pascual, F.D. Vivien, E. Zaccai, Sustainable de-growth: map- ping the context, criticisms and future prospects of an emergent paradigm, Ecol. Econ. 69 (9) (2010) 1741-1747.

[64] B. McKercher, Some fundamental truths about tourism: understanding tourism's social and environmental impacts, J. Sustain. Tour. 1 (1) (1993) 6-16.

[65] D.H. Meadows, D.L. Meadows, J. Randers, W.W. Behrens, The limits to growth. New York, 102, 27, 1972.

[66] G. Merino, et al., Can marine fisheries and aquaculture meet fish demand from a 
growing human population in a changing climate? Glob. Environ. Change 22 (4) (2012) 795-806.

[67] C.M. Moffitt, L. Cajas-Cano, Blue growth: the 2014 FAO State of World Fisheries and aquaculture, Fisheries 39 (11) (2014) 552-553, http://dx.doi.org/10.1080/ 03632415.2014 .966265$.

[68] New Economic Foundation, 2016. Fish Dependence - 2016 Update. The reliance of the EU on fish from elsewhere. Available from: 〈http://b.3cdn.net/nefoundation/ 73291edb051e73af9e_u0m6b1l53.pdf).

[69] S.E. Papoutsoglou, Monitoring and regulation of marine aquaculture in Greece: licensing, regulatory control and monitoring guidelines and procedures, J. Appl. Icthyology 16 (4-5) (2000) 167-171.

[70] D. Pauly, V. Christensen, J. Dalsgaard, R. Froese, F. Torres, Fishing down marine food webs, Science 279 (5352) (1998) 860-863.

[71] D. Pauly, Beyond duplicity and ignorance in global fisheries, Sci. Mar. 73 (2) (2009) 215-224.

[72] D. Pauly, A vision for marine fisheries in a global blue economy, Mar. Policy 87 (2018) 371-374.

[73] F. Schneider, G. Kallis, J. Martinez-Alier, Crisis or opportunity? Economic degrowth for social equity and ecological sustainability. Introduction to this special issue, J. Clean. Prod. 18 (6) (2010) 511-518.

[74] Scientific, Technical and Economic Committee for Fisheries (STECF), Monitoring the performance of the Common Fisheries Policy (STECF-16-03), Luxembourg, Publications Office of the European Union, 2016.

[75] J. Smith, Fishing for self-determination: European fisheries and Western Sahara The case of ocean resources in Africa's Last Colony, in: A. Chircop, S. Coffen-Smout, M. McConnell (Eds.), Ocean Yearbook 27, Martinus Nijhoff Publishers, Leiden, Boston, 2013.

[76] D. Symes, J. Phillipson, Whatever became of social objectives in fisheries policy? Fish. Res. 95 (1) (2009) 1-5.

[77] J.C.J.M. van den Bergh, Environment versus growth - a criticism of "degrowth" and a plea for "a-growth", Ecol. Econ. 70 (5) (2011) 881-890.

[78] C.L. Van Dover, J.A. Ardron, E. Escobar, M. Gianni, K.M. Gjerde, A. Jaeckel, C.R. Smith, Biodiversity loss from deep-sea mining, Nat. Geosci. 10 (7) (2017) 464.

[79] J. Wakefield, Fisheries: a failure of values, Common Mark. Law Rev. 46 (2) (2009) 431-470.

[80] J. Wilkinson, Fish: a global value chain driven onto the Rocks, Sociol. Rural. 46 (2) (2006) 139-153.

[81] World Bank. What is the Blue Economy? Infographic, June 6, 2017. Available from: 〈http://www.worldbank.org/en/news/infographic/2017/06/06/blueeconomy (accessed 15 March 2018).

[82] B. Worm, T.A. Branch, The future of fish, Trends Ecol. Evol. 27 (11) (2012) 594599.

[83] G. Yucel-Gier, O. Uslu, F. Kucuksezgin, Regulating and monitoring marine finfish aquaculture in Turkey, J. Appl. Ichthyol. 25 (6) (2009) 686-694. 